\title{
Сохранение аутосексности кучинских юбилейных кур при разведении по стандарту породы
}

Севастьянова А.А., старший научный сотрудник группы сохранения генофонда

Александров А.В., кандидат сельскохозяйственных наук, научный сотрудник группы сохранения генофонда ФГБНУ Федеральный научный центр «Всероссийский научно-исследовательский и технологический институт птицеводства» Российской академии наук (ФНЦ «ВНИТИП» РАН)

\begin{abstract}
Аннотащия: Исследования по изучению проявления признака аутосексности у кучинских юбилейных кур 6 забисимости от окраски оперения были пробедены на ГППЗ «Кучинский» и предприятии ООО «Генофонд». У Взрослой птицы, которая разбодится по стандарту породы, быявлено нарушение окраски оперения, спровоцированное отбором на аутосексность по признаку светлой окраски крылышек у суточных петушков. С иелью прабильного разбедения породы рекомендобано сдержибать вариацию признака путем протибодействия его распространению у родителей, т.е. быбракобкой особей с белым пером.
\end{abstract}

Ключебые слоба: порода кур кучинская юбилейная, стандарт породы, аутосексность, генетические маркеры, гормон-забисимая экспрессия генов.

Введение. Кучинские юбилейные куры - наиболее распространенная и многочисленная из отечественных пород кур на территории России и Ближнего Зарубежья. Эксперименты по их созданию, как общепользовательной птицы, обладающей высокой жизнеспособностью, начались в 1946 г. Цель селекции новой породы объясняет я.Я. Шаповалов [1]: «Куры иностранных пород общепользовательного типа, неоднократно завозившиеся изза границы, не получили широкого распространения в СССР, т.к. они не были приспособлены к нашим климатическим и хозяйственным условиям». Под его руководством и при непосредственном участии к 1958 г. была проведена основная работа по формированию породной группы кучинских юбилейных кур. В последующие годы специалисты племенного завода ГППЗ «Кучинский», где создавалась эта пти- ца, совершенствовали признаки мясояичной продуктивности, эмбриональной и постэмбриональной жизнеспособности [2]. Порода была утверждена в 1990 г.

Признак аутосексности суточных цыплят по окраске пуха был определен как один из отличительных признаков породы: точность разделения по полу составляла 80-90\% в зависимости от опытности оператора.

Впервые кучинских цыплят стали разделять по полу в суточном возрасте в Узбекистане (на Гиждуванской птицефабрике) и Таджикистане, с точностью около $80 \%$ по окраске крылышек и брюшка, а с 1988 г. - в ГППЗ «Кучинский».

В последующем в госплемптицезаводе был проведен отбор кучинских кур на повышение аутосексности цыплят в суточном возрасте. После проведения отбора изменилась окраска пуха цыплят: у петушков крылышки стали бо- лее светлыми, а разница между курочками и петушками - еще отчетливей. Вследствие проведенного отбора на аутосексность точность разделения суточного молодняка по полу повысилась почти до 95\%. Птица стала более привлекательной для ИПС и птицефабрик с промышленным разведением кучинских юбилейных кур. Однако у взрослой птицы, в частности, У петухов, появилось много белых перьев не только в рулевых, но и в маховых 1 порядка. Фермеры, птицеводы-любители, участники птицеводческих выставок отрицательно отнеслись к изменившейся птице, воспринимали ее как нетипичную и отказывались ее покупать.

Кучинские юбилейные куры первая отечественная порода, для которой был разработан современный стандарт разведения в соответствии с практикой, принятой в международной ассоциации птицеводов [3,4]. По стандар- 
ту [4] белое перо у красно-коричневых пород, особенно в рулевых и маховых перьях, считается недопустимым - брак. Получилось противоречие: повышение аутосексности в суточном возрасте несовместимо с разведением породы по стандарту. Предстояло разобраться: как сохранить полезный отличительный признак породы и освободиться от недостатка.

Материал и методика исследований. Исследования по изучению проявления признака аутосексности у кучинских юбилейных кур в зависимости от окраски оперения взрослой птицы были проведены в ГППЗ «Кучинский» (1988-2003 гг.) и ООО «Генофонд» (1986-2021 гг.) Московской области. Племенные группы комплектовали с окраской оперения у кур: 1) коричневая разной интенсивности; 2) коричневая с наличием крапчатости в поясничной зоне; 3) коричневая с черной окаймленностью пера; 4) коричневая смешанного типа («пунктирный» и «дугообразный» рисунки пера). К ним подбирали петухов соответственно в группы: 1) коричневых; 2) коричневых с черной грудью; 3) коричневых с полулунными черными пятнами на груди; 4) коричневых с неравномерными черными пятнами на груди. Группы отличались генотипом в локусах $E, C o, M l, D b, P g$. На рис. 1-3 приведены примеры птицы с различной окраской оперения.

Потомство отводили от молодой и переярой птицы. Степень аутосексности оценивали по количеству цыплят, пол которых был правильно определен в суточном возрасте. Курочек и петушков в суточном возрасте коль-

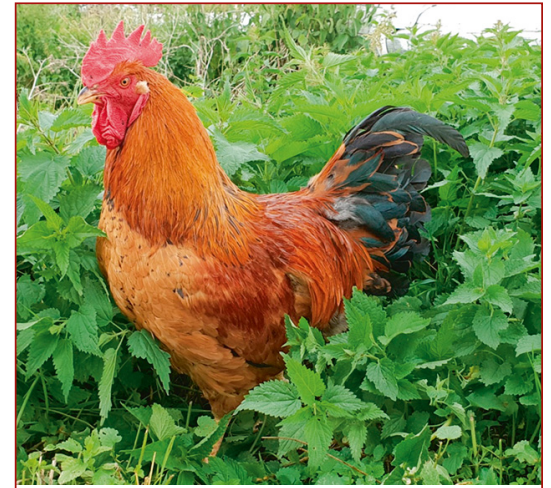

Рисунок 1. Кучинский юбилейный петух (группы №1,4)

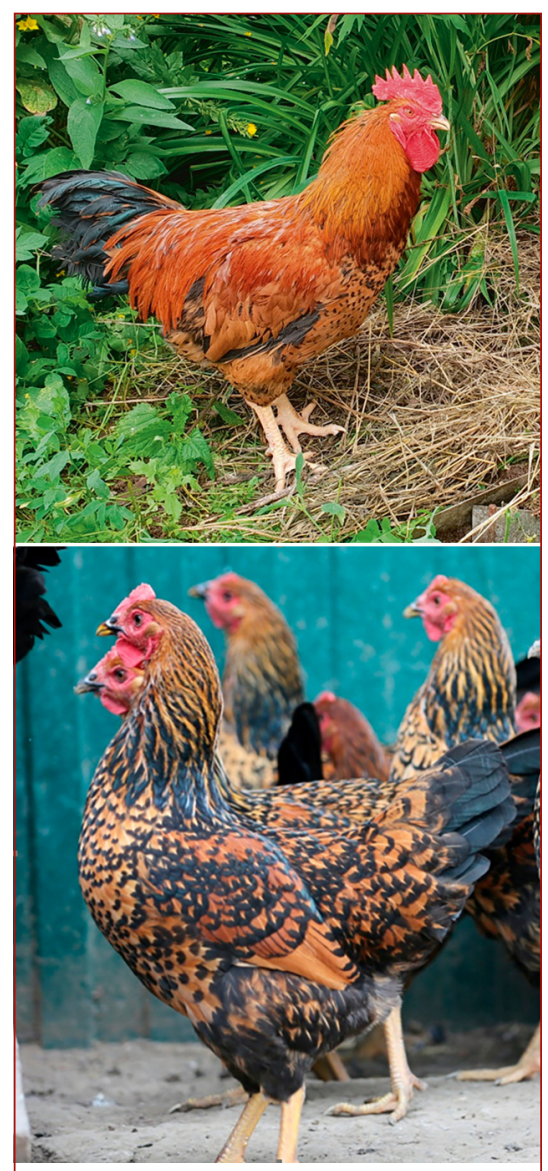

Рисунок 2. Кучинские юбилейные куры (группа №3)

цевали индивидуальными крылометками для повышения точности контроля. Предварительную оценку точности сексирования птицы проводили в возрасте появления вторичных половых признаков: развитие гребня, наличие перьев в кроющем оперении, характерных для петушков (блеск, окраска и форма пера). Общее количество оцененной птицы в ГППЗ «Кучинский» - более 10 тыс. суточных цыплят, на предприятии ООО «Генофонд» - ежегодно не менее 500 голов.

Условия кормления и содержания птицы соответствовали производственным с учетом рекомендаций ВНИТИП.

Результаты исследований и их обсуждение. В 1989 г. один из авторов породы выразил

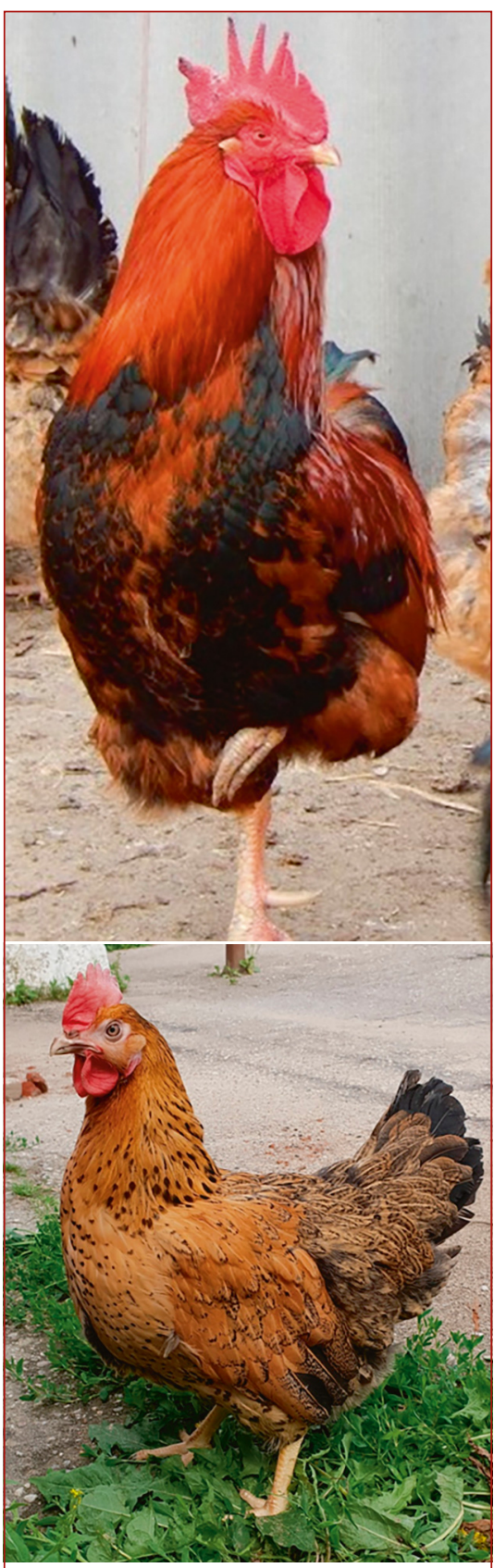

Рисунок 3. Кучинские юбилейные куры (группа №2) 


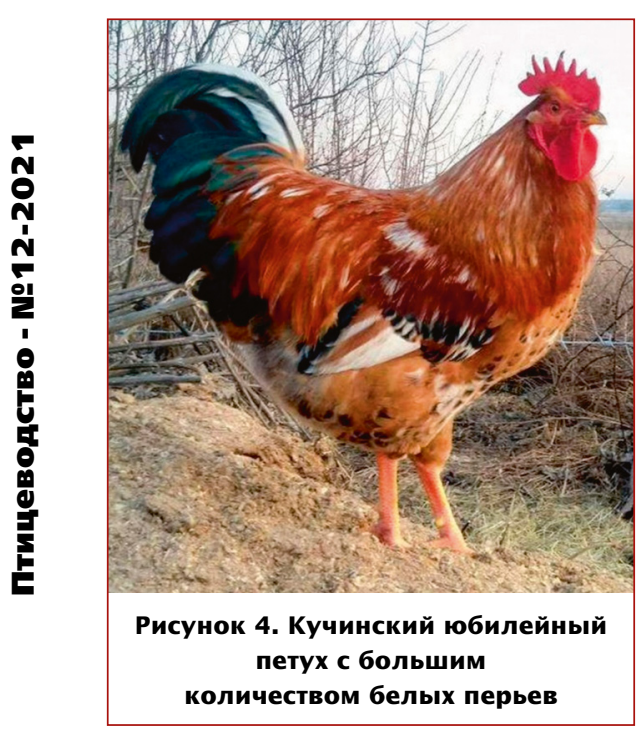

мнение, что у кучинского петуха должно быть одно белое перо в хвосте (рулевые перья). Мы провели многолетние наблюдения за последствиями наличия белого пера у взрослой птицы и ее потомства. По нашим данным, именно такое допущение в окраске оперения петухов способствовало распространению у суточных петушков более светлой окраски крылышек, а у взрослых петухов - появлению белых перьев не только в рулевых, но и в маховых, кроющих груди, поясницы и других зон туловища. Признак хорошо наследуется, обладает высокой вариацией, быстро распространяется у потомства. Однако этот недостаток позволял отчетливее видеть разницу между курочками и петушками в суточ-

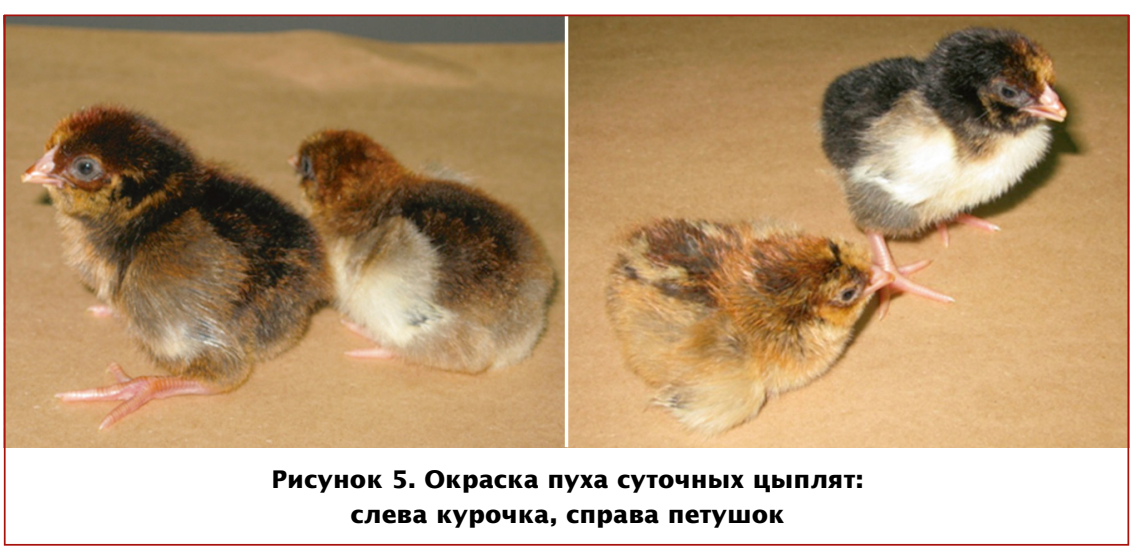

ды к утверждению (поиск и изучение отличительных признаков) в наших исследованиях была получена скорость прироста живой массы петушков к 10-недельному возрасту 27 г/гол./сут. и более (при использовании кормов для бройлеров). Таким образом, более точное разделение цыплят по полу в суточном возрасте очень выгодно: это крупная птица с относительно высоким потреблением корма на единицу прироста живой массы. В связи с этим для поддержания аутосексности, не противоречащей разведению породы по стандарту, нами был проведен отбор в племенном стаде птицы против распространения белой окраски пера. С этой целью была изучена возможность использования различных признаков, связанных с аутосексностью суточных цыплят у кучинских юбилейных кур различной окраски оперения. Результаты оценки представлены в табл. 1. Признаки, использованные для разделения суточных цыплят по полу: 1) окраска крылышек; 2) окраска крылышек и брюшка (рис. 5).

Была проверена также возможность использования признаков окраски головы и спины у суточных цыплят для разделения их по полу. Но они показали низкую эффективность: имели высокую вариацию, оценка занимала много времени и сильно зависела от опыта оператора. Поэтому результаты данного исследования в табл. 1 не включены.

Одновременное использование двух признаков (окраска пуха крылышек и брюшка) дает более высокую точность сексирования. Но окраска крылышек суточных цыплят должна контролировать- 


\begin{tabular}{|c|c|c|c|c|}
\hline \multirow{2}{*}{$\begin{array}{c}\text { Используемые } \\
\text { признаки } \\
\text { фенотипической } \\
\text { оценки }\end{array}$} & \multicolumn{4}{|c|}{ Группы } \\
\hline & 1 & 2 & 3 & 4 \\
\hline Окраска крылышек & 62,1 & 91,0 & 87,0 & 94,0 \\
\hline $\begin{array}{l}\text { Окраска крылышек } \\
\text { и брюшка }\end{array}$ & 68,5 & 93,6 & 97,2 & 95,2 \\
\hline
\end{tabular}

ся путем удаления из племенного стада родителей с наличием в оперении белого пера. Это позволяет сдерживать вариацию признака на уровне, достаточном для эффективного разделения суточного молодняка по полу. Поэтому этот признак следует использовать как дополнительный.

Чтобы не потерять генофонд кучинских юбилейных кур, проведено разделение их на субпопуляции с генами-маркерами, обеспечивающими более высокую однородность этих групп по окраске оперения.

Проведенные исследования показали, что в опытных группах 2 и 3 аутосексность суточных цыплят можно сохранить за счет использования гормон-зависимого проявления комплекса генов, имеющихся в данной породе. Однако степень аутосексности может быть выше при генотипе, ограничивающем распространение черного пигмента на фоне коричневых пигментов (использование неполного доминирования гена Со в одной дозе). Это наблюдается при сочетании генов $s+\mathrm{Co} / \mathrm{co}+\boldsymbol{n}$ рецессивных генов локуса $\mathrm{E}$.

Ранее сообщалось о гормонзависимой экспрессии рецессивных генов локуса E, особенно в присутствии одной дозы колумбийского гена Сo [7]. Наличие гормонов в желтке откладываемых яиц определяет формирование первичных половых различий [8].
По нашим данным, к середине периода инкубации у эмбрионов семенники и яичник определяются четко и очевидно влияют на формирование различной окраски пуха у курочек и петушков.

Сохранив аутосексность на отмеченном выше уровне, к 2020 г. мы наблюдали отдельные случаи встречаемости петухов с белыми перьями, к 2021 г. - от 0 до 1,4\% в разных партиях вывода, против 100\% до 2017 г.

Заключение. Дифференциация птицы по окраске оперения не препятствует проявлению аутосексности в суточном возрасте по признакам окраски пуха живота и крылышек. Для разделения по полу в суточном возрасте следует отдавать предпочтение окраске пуха живота как ведущему признаку, а окраску крылышек использовать как дополнительный признак.

При разведении кучинских юбилейных кур по стандарту породы следует исключать из комплектования гнезд петухов и кур, имеющих белое перо в рулевых, маховых и кроющих перьях. Птица с такой окраской оперения строго недопустима в племенном стаде, ее нельзя использовать как выставочную, однако не следует отрицать принадлежность таких особей к данной породе.

\section{Литература}

1. Шаповалов Я.Я. Кучинские общепользовательные куры и их дальней- шее совершенствование / Я.Я. Шаповалов, А.С. Серебряков, Н.Е. Городкова // Птицеводство. - 1958. - №9. C. 17-19.

2. Копыловская Г.Я. Кучинские юбилейные куры / Г.Я. Копыловская [и др.] // Птицеводство. - 1984. - №2. С. 17-19.

3. Методические рекомендации по работе с птицей породы «Кучинская юбилейная» / А.А. Севастьянова, А.А. Звездина, 3.А. Свирина [и др.]. M., 2008. - 44 c.

4. The American Standard of Perfection // APA, Inc., Burgettstown, Pensilvania, USA. - 2015. - P.33-38.

5. Наставления по сохранению и использованию биоресурсной коллекции сельскохозяйственной птицы / Я.С. Ройтер, А.В. Егорова, Л.Г. Коршунова [и др.]. - Сергиев Посад: ВНИтиП, 2018. - 129 c.

6. Widelitz R.B. Morpho-regulation in diverse chicken feather formation: integrating branching modules and sex hormone dependent morpho-regulatory modules // R.B. Widelitz, G.-W. Lin, Y.Ch. Lai, J.A. Mayer, P.-Ch. Tang [et al.] // Dev. Growth Differ. - 2019. - V.61, No 1. - P. 124-138.

7. Коган 3.М. Признаки экстерьера и интерьера у кур. - Новосибирск: Наука, 1979. - 296 с.

8. Strasser R. Yolk testosterone organizes behavior and male plumage coloration in house sparrows (Passer domesticus) / R. Strasser, H. Schwabl // Behav. Ecol. Sociobiol. - 2004. - V. 56. P. 491-497.

Для контакта с авторами:

\section{Севастьянова}

\section{Антонина Алексеевна}

E-mail:

en-550-60-40@yandex.ru

Александров

Александр Викторович

E-mail:

alexvaleksandrov@gmail.com 


\title{
Conservation of Autosexing Traits together with Breed Standards in the Purebred Kuchinskaya Jubilee Chicken
}

\author{
Sevastyanova A.A, Alexandrov A.V. \\ Federal Scientific Center "All-Russian Research and Technological Institute \\ of Poultry" of Russian Academy of Sciences
}

Summary: The studies on the manifestation of autosexing traits in Kuchinskaya Jubilee chicken breed as affected by the plumage coloration were performed. It was found that the selection of purebred chicken for better autosexing of day-old chicks using light-colored wing fluff in cockerels as a criterion has gradually resulted in the non-standard plumage coloration in adults. Therefore, the conservation of the breed standards requires a more strict control of the variation of this trait and its occurrence in breeders by the culling of individuals bearing white feathers in the plumage.

Keywords: Kuchinskaya Jubilee chicken breed, breed standards, autosexing, genetic markers, hormone dependent gene expression. 